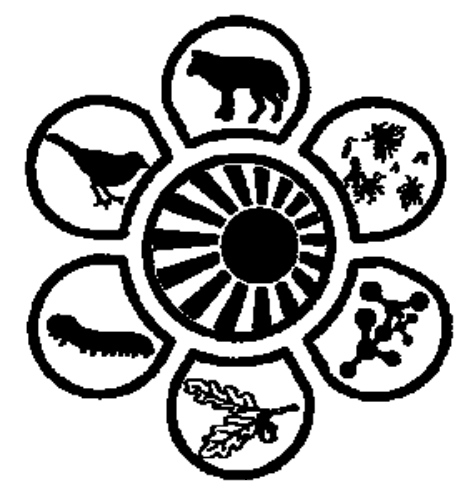

Вісник Дніпропетровського університету. Біологія, екологія.

Vìsnik Dnìpropetrovs'kogo unìversitetu. Seriâ Bìologiâ, ekologiâ

Visnyk of Dnipropetrovsk University. Biology, ecology.

Vìsn. Dnìpropetr. Unìv. Ser. Bìol. Ekol. 2016. 24(2), 466-472.

doi:10.15421/011663

ISSN 2310-0842 print

ISSN 2312-301X online

www.ecology.dp.ua

UDC 632.78

\title{
The problem of assessing the viability of invasive species in the conditions of the steppe zone of Ukraine
}

\author{
K.K. Holoborodko, O.M. Marenkov, V.A. Gorban, Y.S. Voronkova \\ Oles Honchar Dnipropetrovsk National University, Dnipropetrovsk, Ukraine
}

This article proposes a completely new method of resolving the pressing global environmental problem of assessing the capacity of invasive organisms to adapt to new environmental conditions. A new three-step approach to the evaluation of vital and ecological functions of invasive species is recommended. In addition to classic species and population surveys, it was proposed to apply a stress-resistance biochemical assessment of invasive species. Stress resistance can be regarded as the main response of living organisms to changes in continuous environmental components. The obtained results will provide an opportunity to give a qualitative prognisis of what adaptive capacity an invasive species has, what precise ecological functions and for what time period it can perform in a new ecosystem.

Keywords: quarantine species; organism stress resistance; stress measurement technique

\section{Проблема оцінки життєздатності інвазійних видів в умовах степової зони України}

\author{
К.К. Голобородько, О.М. Маренков, В.А. Горбань, Ю.С. Воронкова
}

\author{
Дніпропетровський начіональний університет імені Олеся Гончара, Дніпропетровськ, Украӥна
}

За оцінками ФАО та МСОП, щорічно збільшується кількість видів, які за впливу прямої чи опосередкованої дії людини потрапляють у непритаманні для себе, нові умови. Частина цих організмів, пристосувавшись, починає конкурувати 3 аборигенними видами, втручаючись у сталі екологічні функції різних екосистем. Для європейських країн визначено перелік із 435 видів карантинних організмів, які мають різні статуси небезпеки (як екологічної, так і економічної, адже своєю життєдіяльністю щорічно завдають прямих економічних збитків). Кількість потенційних інвазивних видів, здатних проникнути на територію України, зараз фахівці оцінюють у 1500 видів. Порушення, викликані впливом інвазійних видів, зумовлюють пряму та опосередковану загрозу безпосередньо здоров'ю людини. На початок XXI ст. проблема оцінювання ризиків проникнення інвазійних видів та контролю вже існуючих лежить у царині національної безпеки кожної сучасної держави. Оцінка ризику, який може спричинити життєдіяльність інвазійного виду - це оцінка здатності його організму виживати в умовах нового навколишнього середовища. Аналіз досліджень виживання різних інвазійних видів (рослин, безхребетних і хребетних тварини) показав, що переважна більшість авторів дає оцінку лише видовим і популяційним характеристикам, що у більшості випадків не повною мірою відображає спроможність видувселенця адаптуватись до нових умов довкілля. Отже, потрібно розробити нову методику оцінювання життєздатності інвазійних видів. Запропоновано новий підхід, спрямований на оцінку потенціалу адаптаційних можливостей інвазійних організмів у новому для них середовищі. На відміну від аналогів, запропоновано трирівневий підхід до оцінювання життєдіяльності та екологічних функцій інвазійних видів. Окрім класичних видових і популяційних досліджень, пропонується здійснити біохімічне оцінювання стресостійкості інвазійних видів. Адже стресостійкість можна розглядати як основну реакцію організму на зміни сталих компонентів середовища. Проблема антиоксидантного захисту дуже актуальна в наш час. Але донині немає чіткої відповіді на питання про те, як реагують на вплив різних чинників, на стрес інвазійні організми, потрапляючи до нового середовища, та чому клітина використовує різні захисні системи адаптації до дії одного і того самого чинника. Оксидативний стрес - стан, за якого утворення активних форм кисню (АФК) переважає над процесами їх знешкодження, у результаті чого відбувається порушення основних обмінних процесів. Активні форми кисню разом з антиоксидантами складають систему клітинної редокс-сигналізації, яка, у свою чергу, $\epsilon$ невід'ємним елементом загальної сигнальної мережі як клітини, так і цілого організму. Порушення балансу між утворенням АФК та їх знешкодженням антиоксидантами може спричинювати пошкодження біополімерів, ліпідів та, в кінцевому випадку, -

Дніпропетровський національний університет імені Олеся Гончара, пр. Гагаріна, 72, Дніпропетровськ, 49010, Україна Oles Honchar Dnipropetrovsk National University, Gagarin Ave., 72, Dnipropetrovsk, 49010, Ukraine Tel.: +38-066-795-63-20.E-mail: goloborodko@ua.fm 
загибель клітини. Індукція АФК-залежних шляхів сигнальної трансдукції за впливу різних зовнішніх чинників може спричиняти активацію антиоксидантної системи, а, отже, підвищити стійкість організмів до стресорів різної природи в різних умовах існування. При цьому механізми взаємодії різних компонентів антиоксидантної системи все ще залишаються маловивченими. Незалежно від тривалості життя організму, яка вимірюється днями чи десятилітттями, $\mathrm{O}_{2}$ небезпечний для всіх організмів - рослин, комах, хребетних тварин тощо. Так, комахи не захищені від шкідливої дії АФК. Вони можуть бути особливо схильні до оксидативного стресу. Рослини, потрапляючи до нового середовища, зазнають осмотичного та іонного стресу, які поряд із сольовим стресом можуть викликати розвиток вторинного оксидативного стресу. Останній визначають як короткочасне або тривале підвищення стаціонарної концентрації АФК, що викликає порушення клітинного метаболізму та його регуляції, а також пошкодження клітинних компартментів. У захисті як рослин, так і тварин від дії стресових чинників ключову роль відіграють антиоксиданти, які можуть бути представлені низькомолекулярними сполуками та антиоксидантними ферментами. Запропоновано новий підхід до оцінки стресостійкості інвазійних організмів. Запропоновано розробити нову методику, яка б надала можливість зробити якісний прогноз, які адаптаційні можливості має інвазійний вид і які саме екологічні функції та за який проміжок часу він зможе виконувати в нових для себе екосистемах.

Ключові слова: карантинні види; стресостійкість організму; методика визначення стресостійкості

\section{Introduction}

According to FAO and IUCN estimations, there is an annually increase in the number of animal species which move into new environments, atypical for them, due to direct or indirect human activity. A number of these animals after adaptation begin to compete with native species, invading the stable environmental features of different ecosystems. The result of such penetration can often have irreversible environmental consequences leading to significant biological impairment in the living activities of entire ecosystems, resulting in significant economic waste in various economic sectors. In European countries, a list of 435 quarantine species was drawn up, which have different danger statuses, both environmental and economic, because they annually cause direct economic losses. Nowadays, according to specialist research, the number of potentially invasive species that are able to penetrate into the territory of Ukraine is estimated as 1500 species. Abnormalities in the functioning of the natural ecosystem caused by the influence of invasive species can also bring direct and indirect risk to human health. At the the early XXI century, the challenge of risk assessment on penetration by invasive species and control of existing species is a matter of national security for of every contemporary state.

Research has found that invasive plant species are able to cause significant changes in the soil environment, which is evident in the reduction of $\mathrm{pH}$ levels in the soil solution, changes in $\mathrm{C} / \mathrm{N}$ ratio, increase of $\mathrm{N}$ content (Lazzaro et al., 2004). Along with this, soil characteristics, particularly conditions of contemporary and past land use, are the determining factors of rooting of newer plant species (Csecserits et al., 2016). Changes in environmental conditions in consequence of infestation lead to decrease in biodiversity and biomass productivity of native species, as well as reduction of their toleration (Ruckli et al., 2004; Brygadyrenko, 2015a, $2015 b$ ). However, invasive species often do not lead to deterioration of the environmental state during the first stages of their dispersion (Hulme et al., 2013); this can be determined by application of more sensitive mechanisms to invasion diagnostics compared with environmental changes, particularly use of molecular markers (Wolf et al., 2012).

The results of current researches are devoted to the studies of biology, ecology, and spreading of invasive species in multiple-purpose water bodies (Marlis et al., 2015), as well as the socio-economic consequences of biological invasions (Lotz and Allen, 2013). European scientists conduct the study of migration vectors and spreading of invasive species (Frances et al., 2016), but studies of species adaptive capabilities have almost never been performed.

Living systems are faced with a variety of stresses in the process of their continuous interaction with the environment (Stoliar and Lushchak, 2012). Environmentally induced stresses often activate the production of endogenous reactive oxygen species (ROS), most of which are generated as byproducts of tissue respiration. Thus, the permanent influence of stress factors can exacerbate the ROS-mediated oxidative damages. A large number of agricultural and industrial wastes enter the environment and, thereafter, pass into various living organisms, causing multiple changes in them. Some of effects involve enhancing the direct formation of reactive oxygen, while others can act indirectly, such as by binding to cell thiols and decreasing of antioxidant potential. Pollution of the aquatic environment especially affects fish. However, academic studies on the adaptive capabilities of invasive species have almost never been performed. So, the question of studying the antioxidant support network under development of oxidative stress is quite relevant.

\section{Invasive plant species}

Invasions by non-native species are the greatest global environmental problems in the modern age, which are of particular importance due to processes of biotic globalization (Davis, 2003). Invasive plants pose a significant hazard to biodiversity, ecosystem management, agriculture and forestry, etc. According to assessment of the Convention on Biological Diversity, invasions of non-native species are the second most important threat to biodiversity on the global level, following direct destruction of wildlife habitat (Mack et al., 2000).

In Ukraine, 95 plant species of adventive flora have been identified as the species with high invasive capacity (Protopopova et al., 2002). The most common of these are 21 species (Table 1) (Abduloeva et al., 2008).

In terms of occupied area, and thus in the impact on the local ecosystems, Robinia pseudoacacia ranks first among arboreal species. This species was introduced from South America. It was first introduced to Ukraine in the late XVIII century in Count Razumovsky's Park. In 1808, this plant was grown by I.N. Karazin in his estate in Kharkov region. In Ukraine, $R$. pseudoacacia came actively into cultivation in early 1920s (Vakulyuk and Samoplavskyy, 1998). The species occupies an especially large area within the 
steppe zone, as it is perfectly adapted to arid conditions. $R$. pseudoacacia is a rapid-growth species, and in the first year after planting it grows to $1.5 \mathrm{~m}$, while its stool shoot can reach 2-3 meters in the first year within clear felled areas (Ukraynska ..., 1999). R. pseudoacacia is not a soildemanding tree species. At the present time, under steppe conditions almost everywhere a significant expansion of the distribution of $R$. pseudoacacia is observed; this is related to its growth-inhibiting role in respect to other tree species, such as the oak and ash (Riabchenko, 2012). Invasion of $R$. pseudoacacia into native oak forests can lead to significant changes in forest-site conditions (Nascimbene et al., 2012). At the same time, $R$. pseudoacacia often compares poorly in moistening to steppe herbaceous native species.

Table 1

The most common types of invasive plants in the steppe zone of Ukraine

\begin{tabular}{|c|c|c|c|}
\hline No. & Name of species & Homeland & Year of first registration \\
\hline 1 & Acer negundo Linnaeus (1753) & North America & 1898 \\
\hline 2 & Ailanthus altissima (Mill.) Swingle (1916) & China & 1924 \\
\hline 3 & Ambrosia artemisiifolia Linnaeus (1753) & North America & 1914 \\
\hline 4 & Amorpha fruticosa Linnaeus (1753) & North America & 1809 \\
\hline 5 & Cenchrus longispinus (Hack.) Fernald. (1943) & North America & 1951 \\
\hline 6 & Echinocystis lobata (Mixch.) Torr. et A. Gray. (1840) & North America & 1946 \\
\hline 7 & Helianthus tuberosus Linnaeus (1753) & North America & 1905 \\
\hline 8 & Heracleum mantegazzianum Sommier et Levier (1895) & North America & 1810 \\
\hline 9 & Solidago canadensis Linnaeus (1753) & North America & 1937 \\
\hline 10 & Elodea canadensis Michx. (1803) & North America & 1889 \\
\hline 11 & E. nuttallii (Planch.) St. John. (1920) & North America & 2004 \\
\hline 12 & Reynoutria sachalinensis (F. Schmidt ex Maxim.) Nakai (1988) & Far East & 1936 \\
\hline 13 & Robinia pseudoacacia Linnaeus (1753) & South America & 1808 \\
\hline 14 & Amaranthus albus Linnaeus (1759) & North America & 1861 \\
\hline 15 & Anisantha tectorum (Linnaeus) Nevski (1753) & Southwestern Asia, Northern Africa & 1883 \\
\hline 16 & Asclepias syriaca Linnaeus (1763) & North America & 1904 \\
\hline 17 & Conyza canadensis (Linnaeus) Cronq. (1943) & North America & 1753 \\
\hline 18 & Galinsoga quadriradiata Ruiz and Pav. (1798) & South America & 1946 \\
\hline 19 & G. parviflora Cav. (1795) & South America & 1854 \\
\hline 20 & Impatiens parviflora DC. (1824) & Central Asia & 1927 \\
\hline 21 & Xanthium spinosum Linnaeus (1753) & South America & 1922 \\
\hline
\end{tabular}

Some scientific researches (Abduloeva and Karpenko, 2008) have revealed a high allelopathic activity of $R$. pseudoacacia soluble exudates, which explains to some extent its occupation of new territories and displacement of other plant species. Significant expansion in distribution of $R$. pseudoacacia is also observed in other countries, particularly in Northern Italy there is expansion of the species into new territories (Radtke et al., 2013). In South Korea, expansion of $R$. pseudoacacia occurs within lowlands, and this phenomenon is not observed for uplands (Lee et al., 2004).

\section{Invasive invertebrate species}

Invasive insects are a serious hazard to the local ecosystems and economy. In Ukraine, according to the International Convention on Quarantine and Plant Protection and the International Standards for Phytosanitary Measures (ISPMs
No. 19), lists of quarantine species were compiled. Today in Ukraine 218 species of quarantine organisms are listed in the National List of Regulated Hazardous Organisms, among which 98 species are insects. In the current list, all organisms are divided into three groups:

- A-1 Quarantine organisms absent from Ukraine;

- A-2 Quarantine organisms with restricted distribution in Ukraine;

- Adjustable non-quarantine hazardous organisms.

Species belonging to the A-2 group are the greatest environmental and economic hazards (Table 2) because of their annual irruption. The last 20 years have seen an intense process of fauna transformation in the Dnieper reservoirs. Invasion and distribution of invertebrates occurred (Pligin et al., 2013, Semenchenko et al., 2015). During the period 2000-2015 alone the species composition of the benthos fauna was enrichened by 6 species (Table 3 ).

List of insect species with quarantine status in Ukraine

\begin{tabular}{|c|l|c|c|}
\hline \multicolumn{1}{|c|}{ Name of species } & Homeland & Year of first registration \\
\hline \multicolumn{2}{|c|}{ A-2 Quarantine organisms with restricted distribution in Ukraine } \\
\hline 1 & Diabrotica virgifera virgifera LeConte, 1868 & Central America & 2004 \\
\hline 2 & Frankliniella occidentalis (Pergande, 1895) & North America & 1998 \\
\hline 3 & Hyphantria cunea Drury, 1773 & North America & 1952 \\
\hline 4 & Phthorimaea operculella (Zeller, 1873) Adjustable non-quarantine hazardous organisms \\
\hline \multicolumn{2}{|c|}{ A } & North America \\
\hline 5 & Lopholeucaspis japonica (Cockerell, 1897) & Far East & 1962 \\
\hline 6 & Quadraspidiotus perniciosus Comstock, 1881 & North America & 1876 \\
\hline 7 & Dactylosphaera vitifoliae (Fitch, 1855) & 1880 \\
\hline
\end{tabular}


List of introduced invertebrates in Zaporizhzhya Reservoir (2000-2016)

\begin{tabular}{|c|c|c|c|}
\hline No. & Name of species & Homeland & $\begin{array}{l}\text { Year of first } \\
\text { registration }\end{array}$ \\
\hline \multicolumn{4}{|c|}{ Amphipoda Latreille, 1816} \\
\hline 1 & Synurella ambulans (F. Muller, 1846) & Freshwater habitats in Europe & 2000 \\
\hline 2 & Rivulogammarus kischineffensis Schellenberg, 1937 & Freshwater's South or West Europe & 2001 \\
\hline \multicolumn{4}{|c|}{ Mysidacea A.H. Haworth, 1825} \\
\hline 3 & Katamysis warpachowskyi (Sars, 1893) & $\begin{array}{l}\text { The brackish and freshwaters of the Ponto-Caspian region. Shortly } \\
\text { before 1946, it spread across continental Europe by both intentional (for } \\
\text { fish feeding) and unintentional introductions, and arrived in the coastal } \\
\text { brackish waters of the Baltic and the North Sea. It is soon to be expected } \\
\text { on the Mediterranean coast. The westward spread occurred mainly } \\
\text { through multiple invasion waves along waterways of the southern corri- } \\
\text { dor, from the Danube Delta, through the Main-Danube Channel, and in } \\
\text { the River Rhine down to the North Sea }\end{array}$ & 2007 \\
\hline \multicolumn{4}{|c|}{ Decapoda Latreille, 1802} \\
\hline 4 & Eriocheir sinensis (Milne-Edwards, 1853) & $\begin{array}{l}\text { The coastal estuaries of eastern Asia from Korea in the north to the } \\
\text { Fujian province of China in the south }\end{array}$ & 2002 \\
\hline 5 & Rhithropanopeus harrisii (Gould, 1841) & Atlantic coast of North America & 2009 \\
\hline 6 & Procambarus fallax f. virginalis Martin et al., 2010 & Florida's bodies of freshwater; Germany's bodies of freshwater (since 1990) & 2015 \\
\hline
\end{tabular}

In 2000, in the downstream area of the Samara river an amphipod species new for Ukraine was recorded, S. ambulans. In 2001, in the Kilchen river, was registered the species $R$. kischineffensis, untypical for the steppe of Ukraine and newer for the Dnieper basin, which also expanded its range to the Samara river floodplain. In 2002, in Zaporizhzhya Reservoir, a catch of the mitten crab E. sinensis has been recorded; further reports of catching this species came in 2003 (Kakhovske Reservoir) and 2010-2015 (lower reach of Zaporizhzhya Reservoir) (Novitskiy, 2010).

In the spring of 2009, the Holland crab R. harrisii was found in the Zaporizhzhya Reservoir. In 2015 specimens of marbled crayfish $P$. fallax f. virginalis were first observed (Novitskiy, 2010).

\section{Invasive vertebrate species}

During all stages of existence of the Zaporizhzhya Rservoir, fish fauna has undergone significant transformation. Currently, 52 fish species belonging to 14 families inhabit the reservoir. The number of fish species in the Dnieper in its current form as a chain of huge reservoirs is the same as when it was a free-flowing river, but the composition of fish species has changed radically because of the establishment of new fish species (Fedonenko at al., 2008) (Table 4).

The fauna structure is considerably influenced by the complex of ecological factors that generated changes in ichtyocoenosis. The increase in number of species is associated with various events. Firstly, after disappearance of the Dnieper Rapids and rise of water salinisation, the natural colonizing process began (Fedonenko at al., 2008), resulting in expansion of southern species to the reservoir, such as Alosa pontica, Gasterosteus aculeatus, Syngnathus abaster nigrolineatus, Aterina pontica, Clupeonella cultriventris, Benthophiloides brauneri.

Secondly, some species of fish have been introduced in the reservoir for the purpose of fishery management implementation: Hypophthalmichthys molitrix and Carassius gibelio. In addition to the stocking of the Far-Eastern complex of herbivorous fish, Pseudorasbora parva has become estab- lished in the reservoir; this species unlike white amur and silver carp has acclimatized and expanded its distribution throughout the Zaporizhzhya Reservoir and tributary systems (Bulakhov at al., 2008; Fedonenko at al., 2008).

The emergence of new species was related also to the deliberate release of fish. In such a manner, Lepomis gibbosus appeared in water bodies of Dnipropetrovsk region; the species has adapted successfully and widely enlarged its range (Fedonenko at al., 2015). Because this introduced species is a predator, it can be potentially damaging for valuable commercial fish because it feeds on invertebrates, and occasionally eggs and young fish. At present, about $31 \%$ of the fish species in the Zaporizhzhya Reservoir are introduced. Such changes in the reservoir ichthyofauna composition can harm rational fishing, because introduced species are overwhelmingly the food competitors for the young of commercial fish species.

\section{Determining species viability by stress resistance indices}

Today, the problem of antioxidant protection is very relevant. But, despite the fact that quite a lot is already known about antioxidant system functioning and adjustment, many questions remain unanswered. For example, it remains unclear how the introduced species respond to the impact of various factors and to the stress they experience when they enter a new environment, and why their cells use different protective adapting systems to the same factor of influence (Halliwell, 2007). Oxidative stress is a condition when formation of reactive oxygen species (ROS) prevails over the processes of their disposal, resulting in a major disruption of the main vital processes (Hansen, 2006; Lushchak, 2011). Reactive oxygen forms cause many different damages through oxide modification of lipids, proteins, DNA, and other components. They are by-products of cellular aerobic metabolism, or results of many xenobiotic functions.

Along with antioxidants, reactive oxygen species constitute a system of cellular redox signaling, which is an integral element of the overall signaling system of both cells and the whole organism (Sies, 1991). At the same time, imbalance between ROS formation and their degradation by antioxi- 
dants can lead to damage to biopolymers and lipids and, finally, to cell death. Induction of ROS-dependent pathways of signal transduction influenced by various external factors may cause the activation of the antioxidant system and thus improve organism resistance to stressors of various nature in different conditions of existence. Nevertheless, the mechanisms of interreaction of various components in the antioxidant system still remain unclear.

Distribution of new fish species in the basin of the Zaporizhzhya Reservoir (compiled from data)

\begin{tabular}{|c|c|c|c|}
\hline No. & Name of species & Homeland & $\begin{array}{l}\text { Year of first } \\
\text { registration }\end{array}$ \\
\hline 1 & Syngnathus abaster nigrolineatus Eichwald, 1831 & $\begin{array}{l}\text { Eastern Atlantic: southern Biscay to Gibraltar, and also the Mediterra- } \\
\text { nean and Black seas }\end{array}$ & 1931 \\
\hline 2 & Clupeonella cultriventris (Nordmann, 1840) & Eurasia: Black Sea (northwestern parts), Sea of Azov and Caspian Sea & 1958 \\
\hline 3 & Gasterosteus aculeatus Linnaeus, 1758 & $\begin{array}{l}\text { Circumarctic and temperate regions: Extending south to the Black Sea, } \\
\text { southern Italy, Iberian Peninsula, North Africa; in Eastern Asia north of } \\
\text { Japan }\left(35^{\circ} \mathrm{N}\right) \text {, in North America north of } 30-32^{\circ} \mathrm{N} \text {; Greenland }\end{array}$ & 1959 \\
\hline 4 & Alosa pontica (Eichwald, 1838) & $\begin{array}{l}\text { Eurasia: Black Sea and Sea of Azov (in sea and in the Don, Danube and } \\
\text { other rivers, as much as } 567 \mathrm{~km} \text { up the Don and as far as Kiev on the } \\
\text { Dneiper before the dam was built) }\end{array}$ & $\begin{array}{c}1961 \\
\text { (repeatedly) }\end{array}$ \\
\hline 5 & Ctenopharyngodon idella (Valenciennes, 1844) & Asia: China to eastern Siberia (Amur River system) & $1960-1970$ \\
\hline 6 & Carassius gibelio (Bloch, 1782) & $\begin{array}{l}\text { Originally from Asia (Siberia), they have been introduced to and now } \\
\text { inhabit lakes, ponds, and slow-moving rivers throughout Europe, North } \\
\text { America, and Asia }\end{array}$ & 1970 \\
\hline 7 & Aristichthys nobilis (Richardson, 1845) & $\begin{array}{l}\text { Bighead carp are native to the large rivers and associated floodplain lakes } \\
\text { of eastern Asia. Their range extends from southern China north to the } \\
\text { Amur River system, which forms the border between China and Russia }\end{array}$ & 1970 \\
\hline 8 & Hypophthalmichthys molitrix (Valenciennes, 1844) & Freshwaterbodies of China and eastern Siberia & 1970 \\
\hline 9 & Atherina pontica (Eichwald, 1831) & $\begin{array}{l}\text { Eastern Atlantic: Portugal and Spain to Nouadhibou in Mauritania and } \\
\text { Madeira, and throughout the Mediterranean and Black Sea }\end{array}$ & 1990 \\
\hline 10 & Pseudorasbora parva (Temminck et Schlegel, 1846) & Asia: Amur to Zhujiang [Pearl River] drainages in Siberia, Korea and China & 1992 \\
\hline 11 & Mesogobius batrachocephalus (Pallas, 1814) & Europe and Asia: Black Sea, and Sea of Azov & 1995 \\
\hline 12 & Ictalurus punctatus (Rafinesque, 1818) & $\begin{array}{l}\text { North America: Central drainages of the United States to southern Can- } \\
\text { ada and northern Mexico }\end{array}$ & 1996 \\
\hline 13 & Lepomis gibbosus (Linnaeus, 1758) & $\begin{array}{l}\text { North America: New Brunswick in Canada to South Carolina in the } \\
\text { USA; Great Lakes, Hudson Bay and upper Mississippi basins from } \\
\text { Quebec and New York west to southeast Manitoba and North Dakota, } \\
\text { and south to north Kentucky and Missouri }\end{array}$ & $\begin{array}{l}1992-1993 \\
2002\end{array}$ \\
\hline 14 & Benthophiloides brauneri (Beling et Iljin, 1927) & Eurasia: Black Sea, Sea of Azov, and Caspian Sea estuaries and rivers & 2006 \\
\hline
\end{tabular}

Regardless of a longevity duration that can be days or decades, $\mathrm{O}_{2}$ is dangerous for all living organisms, whether plants, insects, and vertebrates. For example, insects are not protected from the harmful ROS effect occurring at $\mathrm{O}_{2}$ reduction. Insects can be particularly prone to oxidation stress (Felton, 1995). On reaching a new environment, plants are exposed to osmotic and ionic stresses that along with saline stress can cause the development of secondary oxidation stress. Oxidation stress is defined as short-term or prolonged increasing of steady-state ROS concentration, which causes disturbance of cell metabolism and its regulation processes as well as damaging the cellular compartments (Apel, 2004). Antioxidants play the key role in protection both plants and animals against the effects of stress factors; antioxidants can be represented by low-molecular compounds and antioxidant enzymes (Blokhina, 2003; Gill, 2010).

Superoxide dismutase and catalase are enzymes of the first line of defense against ROS. Superoxide dismutase (SOD, F.K. 1.15.1.1) is a permanent component of the antioxidant system. SOD catalyzes the dismutacion $\mathrm{O}_{2}{ }^{\circ}$ to $\mathrm{H}_{2} \mathrm{O}_{2}$. Activity of SOD is related to redox-active metal ion in the molecular active center of the enzyme, and, depending on the enzyme type, that ion may be manganese, ferrum or cuprum, which is involved in the process of radical neutralization. At the first step, one-electron oxidation takes place, and the oneelectron reduction at the second step. These reactions do not require an external source of oxidation-reduction equivalents, so they are independent components of the antioxidant system (Kohen, 2002).

Catalase (F.K. 1.11.1.6) is an enzyme that is present in most anaerobic cells, and it catalyzes the transformation reaction of hydrogen peroxide to water and oxygen. In animal tissues, catalase is localized in the cytoplasm and peroxisomes. Catalases represents a large group of oxido-reductases, which are divided into three subgroups, depending on the physical and biochemical properties (Kohen, 2002; Halliwell, 2007). Most aerobic organisms contain catalase except some algae and parasitic helminths (Imlay, 2003).

Different redox groups can be used as indicators of changes in cell oxidation-reduction balance (Hansen, 2006; Lushchak, 2011). In the cell, there are three basic oxidationreduction systems. The eukaryote basic reduction systems supporting cell oxidation-reduction balance includes the glutathione-dependent system (GSH/GSSG) (Anderson, 1998). Glutathione acts as the most important intracellular lowmolecular thioic antioxidant. The importance of glutathione in the cell is determined by its antioxidant properties. Actually glutathione not only protects the cell from such toxic agents as free radicals, but also determines the redox status of the intracellular environment generally (Anderson, 1998; Lushchak, 2012). 


\section{Conclusion}

We propose a completely new advanced technique aimed at addressing the modern global environmental target of evaluation of potential adaptive capacities of invasive species in new environments. Unlike its analogues, the proposed three-step approach in evaluation of life activity and ecological functions of invasive species has been developed. In addition to the classic species and population surveys, it was proposed to carry out biochemical evaluation of stress resistance in invasive species. After all, stress resistance can be considered as the primary reaction of living organisms to changes of stable environment components. The results will provide the opportunity to make a more accurate forecast concerning adaptation opportunities in invasive species, and exactly what kind of ecological functions and for which time period such species will be able to perform in the ecosystems new to them.

\section{References}

Abduloeva, O.S., Karpenko, N.I., Senchylo, O.O., 2008. Obgruntuvannia "chornogo spysku" zagrozlyvykh dlia bioriznomanittia invaziynykh vydiv roslyn Ukrainy [Justification of "the black list" threatening the biodiversity of invasive species Ukraine]. Visnyk Kyivskogo Natsionalnogo Unirsytetu. Seria Biologiia 52-53, 106-107 (in Ukrainian).

Anderson, M.E., 1998. Glutathione: An overview of biosynthesis and modulation. Chem. Biol. Interact. 111, 1-14.

Apel, K., Hirt, H., 2004. Reactive oxygen species: Metabolism, oxidative stress and signal transduction. Ann. Rev. Plant Biol. 55, 373-399.

Blokhina, O., Virolainen, E., Fagerstedt, K.V., 2003. Antioxidants, oxidative damage and oxygen deprivation stress: A review. Ann. Bot. 91, 179-194.

Brygadyrenko, V.V., 2015a. Evaluation of the ecological niche of some abundant species of the subfamily Platyninae (Coleoptera, Carabidae) against the background of eight ecological factors. Folia Oecol. 42(2), 1-18.

Brygadyrenko, V.V., 2015b. Parameters of ecological niches of Badister, Licinus and Panagaeus (Coleoptera, Carabidae) species measured against eight ecological factors. Baltic Journal of Coleopterology 15(2), 137-154.

Bulakhov, V.L., Novitskiy, R.O., Pakhomov, O.Y., Hristov, O.A., 2008. Biolohichne riznomanittya Ukrayiny. Dnipropetrovska oblast. Kruhloroti (Cyclostomata). Ryby (Pisces) [Biological diversity of Ukraine. Dnipropetrovsk region. Cyclostomes (Cyclostomata). Fish (Pisces)]. Dnipropetrovsk University Press, Dnipropetrovsk (in Ukrainian).

Csecserits, A., Botta-Dukát, Z., Kröel-Dulay, G., Lhotsky, B., Ónodi, G., Rédei, T., Szitár, K., Halassy, M., 2016. Tree plantations are hot-spots of plant invasion in a landscape with heterogeneous land-use. Agr. Ecosyst. Environ. 226, 88-98.

Davis, M., 2003. Biotic globalization: Does competition from introduced species threaten biodiversity? BioScience 53, 481-489.

Fedonenko, O.V., Yesipova, N.B., Sharamok, T.S., Ananyeva, T.V., Yakovenko, V.O., Zhezherya, V.A., 2008. Ekolohichnyy stan biotsenoziv Zaporizkoho vodoskhovyshcha v suchasnykh umovakh [Ecological state of Zaporozhye Reservoir biocenoses under current conditions]. Dnipropetrovsk University Press, Dnipropetrovsk (in Ukrainian).

Fedonenko, O.V., Yesipova, N.B., Marenkov, O.M., Sharamok, T.S., 2015. Kontseptsiya rozvytku rybnoho hospodarstva Dnipropetrovs'koyi oblasti na nastupni pyat rokiv [The concept of development of fisheries of Dnipropetrovsk region for the next five years]. Rybohospodarska Nauka Ukrayiny 31, 16-25 (in Ukrainian).

Felton, G.W., Summers, C.B., 1995. Antioxidant systems in insects. Arch. Insect Biochem. Physiol. 29(2), 187-197.

Gill, S.S., Tuteja, N., 2010. Reactive oxygen species and antioxidant machinery in abiotic stress tolerance in crop plants. Plant Physiol. Biochem. 48, 909-930.

Halliwell, B., Gutteridge, J.M.C., 2007. Free radicals in biology and medicine. Free Radic. Biol. Med. 10(6), 449-450.

Hansen, J.M., Go, Y.M., Jones, D.P., 2006. Nuclear and mitochondrial compartmentation of oxidativestress and redox signaling. Annu. Rev. Pharmacol. Toxicol. 46, 215-234.

Hulme, P.E., Pyšek, P., Jarošík, V., Pergl, J., Schaffner, U., Vilà, M., 2013. Bias and error in understanding plant invasion impacts. Trends Ecol. Evol. 28(4), 212-218.

Imlay, J.A., 2003. Pathways of oxidative damage. Annu. Rev. Microbiol. 57(1), 395-418.

Kohen, R., Nyska, A., 2002. Oxidation of biological systems: Oxidative stress phenomena, antioxidants, redox reactions, and methods for their quantification. Toxicol. Pathol. 30(6), 620-650.

Lazzaro, L., Giuliani, C., Fabiani, A., Agnelli, A.E., Pastorelli, R., Lagomarsino, A., Benesperi, R., Calamassi, R., Foggi, B., 2014. Soil and plant changing after invasion: The case of Acacia dealbata in a Mediterranean ecosystem. Sci. Total Environ. 497, 491-498.

Li, G., Xu, G., Guo, K., Du, S., 2014. Mapping the global potential geographical distribution of Black Locust (Robinia pseudoacacia L.) using herbarium data and a maximum entropy model. Forests 5, 2773-2792.

Lotz, A., Allen, C.R., 2013. Social-ecological predictors of global invasions and extinctions. Ecol. Soc. 18(3), 15.

Lushchak, V.I., 2011. Adaptive response to oxidative stress: Bacteria, fungi, plants and animals. Comp. Biochem. Physiol. C Toxicol. Pharmacol. 153(2), 175-190.

Lushchak, V.I., 2012. Glutathione homeostasis and functions: Potential targets for medical interventions. J. Amino Acids 2012, Article ID 736837.

Mack, R.N., Simberloff, D., Lonsdale, W.M., Evans, H., Clout, M., Bazzaz, F.A., 2000. Biotic invasions: Causes, epidemiology, global consequences and control. Ecological Applications 10(3), 689-710.

Nascimbene, J., Nimis, P.L., Benesperi, R., 2012. Mature nonnative black-locust (Robinia pseudoacacia L.) forest does not regain the lichen diversity of the natural forest. Sci. Total Environ. 421-422, 197-202.

Novitskiy, R.O., 2010. Novi vydy hidrobiontiv-autovselentsiv u Dniprovs'komu vodoskhovyshchi [New species of self establishing hidrobionts in the Dnieper reservoir]. Naukovi Zapysky Ternopilskoho Natsionalnoho Pedahohichnoho Universytetu. Seriya Biolohiya 43, 373-376 (in Ukrainian).

Novitskiy, R.O., Semenova, O.V., 2010. Morfo-ekolohichna kharakterystyka oseledtsya chornomorsko-azovskoho Alosa pontica pontica Dniprovs'koho (Zaporizkoho) vodoskhovyshcha [Morpho-ecological characteristics of the AzovBlack Sea herring Alosa pontica pontica of Dnieper (Zaporizhia) Reservoir]. Pytannya Bioindykatsiyi ta Ekolohiyi 14(2), 204-214 (in Ukrainian).

Pligin, Y.V., Matchinskaya, S.F., Zhelezniak, N.I., Linchuk, M.I., 2013. Distribution of alien species of macroinvertebrates in the Dnieper Reservoirs in long-term aspect. Hydrobiological Journal 49(6), 21-36.

Protopopova, V.V., Mosiakin, S.L., Shevera, M.V., 2002. Fitoinvazii v Ukraini iak zagroza bioriznomanittyu: Suchasnyy stan i zavdannia na maybutne [Phytoinvasions in Ukraine as a threat to biodiversity: Current status and challenges ahead]. Instytut Botaniky NAN Ukrajiny, Kyiv (in Ukrainian).

Riabchenko, M.M., 2012. Nasadzhennia robinii pseudoakatsii v umovakh tsentralnoi chastyny Prydniprovskoi vysochyny [Plantation of Robinia pseudoacacia in the central part of 
the Dnieper Plateau]. Naukovyy Visnyk Natsionalnogo Universytetu Bioresursiv i Pryrodokorystuvannia Ukrainy. Seria Lisivnytstvo ta Dekoratyvne Sadivnytstvo 171(2), 166171 (in Ukrainian).

Ruckli, R., Rusterholz, H.-P., Baur, B., 2014. Invasion of an annual exotic plant into deciduous forests suppresses arbuscular mycorrhiza symbiosis and reduces performance of sycamore maple saplings. Forest Ecol. Manag. 318, 285-293.

Semenchenko, V.P., Son, M.O., Novitsky, R.A., Kvatch, Y.V., Panov, V.E., 2015. Alien macroinvertebrates and fish in the Dnieper River basin. Russian Journal of Biological Invasions 6(1), 51-64.

Sies, H., 1991. Role of reactive oxygen species in biological processes. J. Mol. Med. (Berl.) 69(21), 965-968.
Stoliar, O.B., Lushchak, V.I., 2012. Oxidative stress - environmental induction and dietary antioxidants [Environmental pollution and oxidative stress in fish]. InTech 132-166.

Vakulyuk, P.G., Samoplavskyy, V.I., 1998. Lisovidnovlennia ta lisorozvedennia $\mathrm{v}$ rivnynnykh rayonakh Ukrayny [Reforestation and afforestation in the plain areas of Ukraine]. Polifast, Fastiv (in Ukrainian).

Wolf, V.C., Gassmann, A., Clasen, B.M., Smith, A.G., Müller, C., 2012. Genetic and chemical variation of Tanacetum vulgare in plants of native and invasive origin. Biol. Control 61(3), 240-245.

Надійшла до редколегії 11.10.2016 